\title{
Is every intussusception treatment an emergency intervention or surgery?
}

\author{
Lütfi Hakan Güney, M.D., Ender Fakıoğlu, M.D., Tuğba Acer, M.D., İbrahim Ötgün, M.D., \\ Esra Elif Arslan, M.D., Müge Sağnak Akıllı, M.D., Akgün Hiçsönmez, M.D.
}

Department of Pediatric Surgery, Başkent University Faculty of Medicine, Ankara-Turkey

\begin{abstract}
BACKGROUND: Intussusception is the second most common cause of acute abdomen in children, following appendicitis. The aim of the present study was to evaluate the experience of the authors, in an effort to promote intussusception management, especially that of small bowel intussusception.
\end{abstract}

METHODS: Records of intussusception diagnosed between July 2002 and September 2014 were evaluated in terms of patient age, sex, clinical findings, admission time, ultrasonographic findings, treatment methods, and outcomes.

RESULTS: Eighty-one patients, 52 males and 29 females, were included (mean age: 10.6 months). Intussusceptions were ileocolic (IC) in 52 cases, ileoileal (IL) in 26, and jejunojejunal (JJ) in 3. Nineteen (23.5\%) patients underwent surgery. Hydrostatic reduction was performed in 45 (55.5\%) IC cases. Seventeen (2I\%) patients with small bowel intussusceptions (SBIs), measuring I.8-2.3 cm in length, spontaneously reduced. All patients who underwent surgery had intussusceptums $\geq 4 \mathrm{~cm}$. Three of the 4 intestinal resection cases had history of abdominal surgery.

CONCLUSION: If peritoneal irritation is present, patients with intussusception must undergo surgery. Otherwise, in patients with IC intussusception and no sign of peritoneal irritation, hydrostatic or pneumatic reduction is indicated. When this fails, surgery is the next step. SBls free of peritoneal irritation and shorter than $2.3 \mathrm{~cm}$ tend to spontaneously reduce. For those longer than $4 \mathrm{~cm}$, particularly in patients with history of abdominal surgery, spontaneous reduction is unlikely.

Keywords: Benign intussusception; intussusception; small bowel intussusceptions; spontaneous reduction; transient intussusception.

\section{INTRODUCTION}

Intussusception is the second most common cause of acute abdomen in children, following appendicitis. ${ }^{[1-3]}$ It occurs most frequently in the first 3 years of life, and peaks between the third and ninth months. Sudden onset of vomiting, intermittent abdominal pain, and rectal bleeding in the form of currant jelly are typical symptoms. ${ }^{[3-5]}$ While aspects of etiology still require clarification, upper respiratory tract infection, adenovirus-associated gastroenteritis, and particularly rotavirus vaccine and infection have been widely

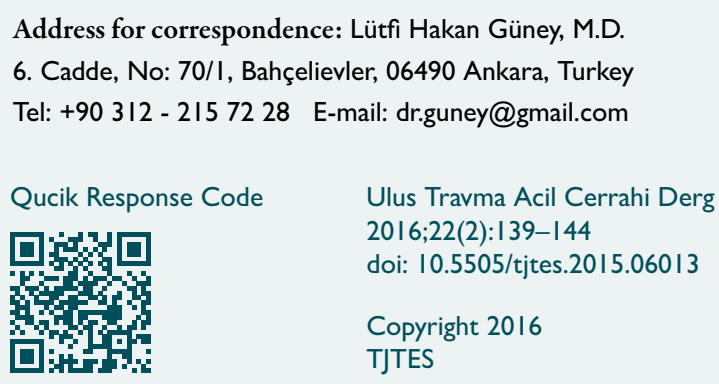

thought to contribute. ${ }^{[6-10]}$ If treatment is delayed, cascade beginning with vascular congestion and edema of intussuscepted intestinal wall may demonstrate a highly morbid, even fatal course, with tissue ischemia, necrosis, and intestinal perforation. ${ }^{[1]}$

Intussusception is diagnosed based on characteristic findings of target (doughnut) and/or pseudokidney signs on ultrasonography (USG), which is highly accurate. ${ }^{[12,13]}$

Depending on the clinical situation, treatment for ileocolic (IC) and colocolic (CC) intussusception may be non-surgical (pneumatic or hydrostatic pressure enemas under fluoroscopy or USG) or surgical (operative, manual reduction and/or resection or enterostomy intervention as needed).

If spontaneous reduction of small bowel intussusceptions (SBIs) does not occur, the only means of reduction is surgery. The terms "transient" or "benign" intussusception are used for those that have spontaneously reduced. However, criteria to determine the treatment of choice (surgery or observation) has been a subject of debate. ${ }^{[12]}$ 
The aim of the present study was to evaluate experience with intussusception between July 2002 and September 2014, and to gather data in an effort to promote management of intussusception, particularly $\mathrm{SBI}$, a debated issue.

\section{MATERIALS AND METHODS}

At the authors' hospital, intussusception is almost always diagnosed in an emergency setting. Pediatric surgeons are consulted by pediatric emergency physicians on patients suspected of having diseases that require surgery upon presenting to emergency department. When history and physical examination suggest intussusception, definite diagnosis is reached upon confirmation with USG findings. Pediatric surgeons are consulted also on patients incidentally reported to have intussusception on USG performed for other reasons. Once diagnosed, reduction of IC or CC intussusception is attempted as soon as possible, either surgically or non-surgically, depending upon the patient's clinical situation. For cases of ileoileal (IL) and jejunojejunal (JJ) intussusception free of clinical deterioration, intestinal obstruction, and acute abdominal findings, preferred treatment is close observation, with physical examination every 2 hours and USG at least once every 12 hours. After the first eventless 24-hour-period, the patient is fed orally, and is discharged following the second eventless period. Upon sign of clinical deterioration with persisting intussusception on USG, surgery is performed.

Cases registered in the electronic database of a tertiary health care center (university hospital) with an ICD-10 code of "intussusception," indicating definite diagnosis, between July 2002 and September 2014 were retrospectively reviewed. Records were evaluated in terms of patient age, sex, clinical signs upon presentation, admission time, USG data, intussus- ception type, and treatment methods.

Statistical assessment of data was conducted by the biostatistics department. SPSS software (version 20.0; SPSS Inc., Chicago, IL, USA) was used for data analysis.

The present study was approved by the local institutional review board (Project no: KAI5/50).

\section{RESULTS}

A total of 81 patients, 52 males and 29 females, were included. Mean age was 10.6 months ( $1-102$ months). When grouped according to age (younger than I year old, aged between I and 4 years, and older than 4 years), the groups included 27 , $4 \mathrm{I}$, and 13 patients, respectively. Based on USG findings, 3 types of intussusception were detected: IC, IL, and JJ. Distribution of types among age groups is presented in Table $\mathrm{I}$.

USG was performed by the USG team of the department of radiology, which comprises 5 academic staff members.

Chief complaint was abdominal pain in all patients. Additional complaint was vomiting in 67 cases (82.7\%), and blood in stool in 10 cases (12.4\%). Abdominal mass was palpated in 5 cases (6.2\%). Intussusceptions were IC in 52 patients, IL in 26 patients, and JJ in 3 patients.

One of the 52 IC intussusception cases underwent immediate surgery due to acute abdomen. In 45 ( $55.6 \%$ of total) of the remaining $5 \mathrm{I}$ cases, hydrostatic reduction was ensured with barium enema concomitant with fluoroscopy. Surgery was performed as needed following unsuccessful hydrostatic reduction attempts in $6 \mathrm{IC}$ intussusception cases.

Table I. Types of intussusception according to age groups

\begin{tabular}{lcccc}
\hline & Ileo-colic & Ileo-ileal & Jejuno-jejunal & Total \\
\hline$<$ y.o.* & 22 & 5 & - & 27 \\
I-4 y.o. & 25 & 15 & 1 & $4 \mathrm{I}$ \\
$>4$ y.o. & 5 & 6 & 2 & 13 \\
Total & 52 & 26 & 3 & $8 \mathrm{I}$ \\
\hline *Year(s) old. & & & &
\end{tabular}

Table 2. Types of intussusception according to management

\begin{tabular}{lcccc}
\hline & lleo-colic & lleo-ileal & Jejuno-jejunal & Total \\
\hline Hydrostatic reduction & 45 & - & - & 45 \\
Surgery & 7 & $1 \mathrm{I}$ & $\mathrm{I}$ & 19 \\
Follow-up & - & 15 & 2 & 17 \\
Total & 52 & 26 & 3 & $8 \mathrm{I}$ \\
\hline
\end{tabular}


Table 3. Admission times according to management

\begin{tabular}{|c|c|c|c|c|c|}
\hline Admission time & Invaginated segment & Surgery & Hydrostatic reduction & Follow-up & Total \\
\hline \multirow[t]{3}{*}{$<24$ hours } & Ileo-colic & - & 18 & - & 30 \\
\hline & Ileo-ileal & - & - & II & \\
\hline & Jejuno-jejunal & - & - & 1 & \\
\hline \multirow[t]{3}{*}{ 24-72 hours } & Ileo-colic & 2 & 18 & - & 27 \\
\hline & Ileo-ileal & 4 & - & 3 & \\
\hline & Jejuno-jejunal & - & - & - & \\
\hline \multirow[t]{3}{*}{$>72$ hours } & Ileo-colic & 5 & 9 & - & 24 \\
\hline & Ileo-ileal & 7 & - & 1 & \\
\hline & Jejuno-jejunal & 1 & - & 1 & \\
\hline Total & & 19 & 45 & 17 & 81 \\
\hline
\end{tabular}

Nineteen patients $(23 \%)$ received surgical treatment, 7 for IC, II for IL, and I for JJ intussusception (Table 2). Mean age of patients who underwent surgery was 3.4 years (min: 7

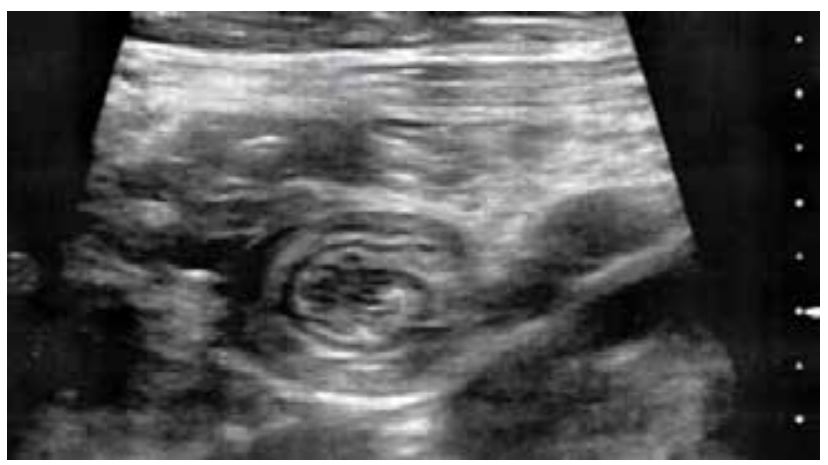

Figure 1. Typical pseudokidney sign (doughnut sign) indicating IL intussusception. Ultrasonographic view from the right paraumbilical region of a patient with transient SBI.

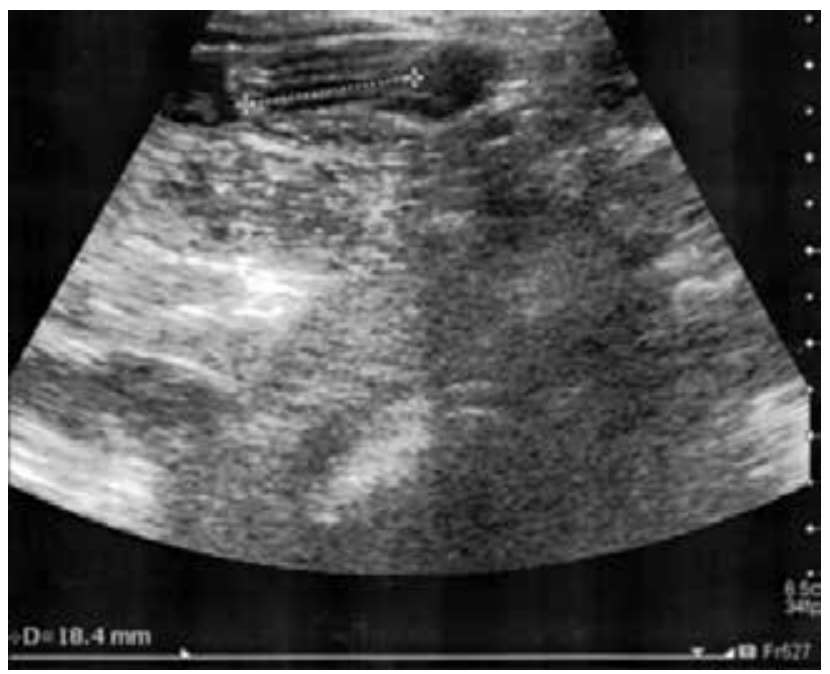

Figure 2. A 4-year-old male with transient SBI. Ultrasonographic view of intussusceptum with a vertical section, $1.84 \mathrm{~cm}$ in months, max: 8.5 years). Intestinal resection was performed in 4 of the patients who underwent surgery, all of whom had IL intussusception, with intussuscepted segments ranging between 4 and $10 \mathrm{~cm}$ in length. Manual reduction was performed in the remaining 15 patients who underwent surgery, with intussuscepted segments ranging from 4 to $12 \mathrm{~cm}$. Three of the 15 patients had undergone prior abdominal surgery; I had undergone liver transplantation (J) and 2 had undergone intra-abdominal tumor surgery (IL). Among the 19 patients who received surgical treatment, no leading point was detected in 7 (36.8\%). Leading points detected in the others were lymph nodes in 10 (52.6\%), Meckel's diverticulum in I, (5.3\%) and mesenteric cyst in I (5.3\%).

Thirty patients presented to emergency department in the first 24 hours following onset of symptoms. None required surgery; hydrostatic reduction was performed in 18 (60\%) and 12 patients (40\%) were observed until spontaneous reduction occurred. Twenty-seven patients presented to emergency department services 24-72 hours after symptom onset, 6 of whom (22.2\%) underwent surgery, while 18 (66.7\%) underwent hydrostatic reduction, and 3 (II.I\%) were observed. Twenty-four patients presented more than 72 hours after symptom onset, 13 of whom (54.2\%) underwent surgery, while 9 (37.5\%) underwent hydrostatic reduction, and 2 (8.3\%) were observed until spontaneous reduction occurred (Table 3 ).

Diagnostic USG of IL and J intussusceptions revealed lengths of 4-12 cm (mean: 6.I; median: 5.9) in patients who had undergone surgery, while lengths of intussusceptums that had spontaneously reduced were between 10 and $23 \mathrm{~mm}$ (mean: 18; median 20; Figs I, 2). No mortality or morbidity was observed.

\section{DISCUSSION}

If diagnosed early, IC intussusception may be easily treated 
by non-surgical methods including hydrostatic or pneumatic reduction. Surgery is indicated when non-surgical methods fail, or when intestinal perforation or peritoneal irritation is present. Manual reduction, if possible, is the primary goal of surgery. Intestinal necrosis, perforation and sepsis may complicate intussusception, requiring more extensive surgery such as intestinal resection, longer hospital stays; even resulting in mortality in late diagnosed patients. ${ }^{[14,15]}$ Tran et al. reported in a study that included patients from 14 countries that reported rates of surgically treated intussusception range between $2.5 \%$ and $95 \%$. The authors attributed this enormous range to differences in ease of hospital accessibility and divergent intervals between onset time of symptoms and treatment initiation time after arrival to hospital (due to local factors). The authors also noted the potential mistake of recording surgically treated intussusception cases in diagnosis databases with codes for gastrointestinal diseases rarely associated with intussusceptions or for potential complications of intussuscep-

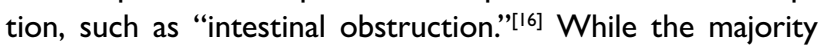
(5I cases, 63\%) were diagnosed at least 24 hours after onset of the symptoms, $23.5 \%$ of cases required surgery. Of the 19 patients who underwent surgery, only 4 (4.9\% of the total patient population) required resection of necrotic intussuscepted intestinal segments. All 4 were admitted at least 72 hours after onset of symptoms. This emphasizes the importance of timely intervention and that complaints of abdominal pain and vomiting should not be underestimated. ${ }^{[3,4,17]}$

Hydrostatic or pneumatic reduction is the first treatment option in childhood cases of IC or CC intussusception without perforation and/or peritonitis. Barium and physiological saline solution are used for enema in hydrostatic reduction under fluoroscopic or ultrasonographic vision. No widely accepted, prominent superiority of these methods has been reported in any large, controlled, prospective study. ${ }^{[15,18,19]}$ Experience, personal preference, expertise of the physician involved, and local conditions are the main determinants of the choice of technique. ${ }^{[18]}$ Hydrostatic reduction with barium enema under fluoroscopy was performed in the present study, with a reduction success of $88.2 \%$ (45 of $5 \mathrm{I}$ reduction attempts), which is acceptable, compliant with the overall success rate for all nonsurgical reduction techniques and higher than the reported success rate of hydrostatic reduction under fluoroscopy in the literature. ${ }^{[18]}$ No complication was encountered.

Incidences of IL and J intussusception are considerably lower, compared to IC intussusception. ${ }^{[20]}$ According to the literature, underlying disease and a leading point are generally suspected to exist in cases of SBI, which mostly occur in older children, and surgery is reportedly indicated. ${ }^{[21-23]}$ Classical symptoms may be lacking in cases of SBI, which may prolong the diagnosis period and lead to severe consequences. ${ }^{[12]}$ In spite of such dire consequences, possibility of spontaneous reduction of SBls should be considered. ${ }^{[16,24,25]}$ Of the 81 patients in the present study, 17 had SBI (I5 IL, $2 \mathrm{JJ})$ that reduced spontaneously.
Among the patients who underwent surgery, 12 had SBI, I I had IL, and I had JJ intussusception, the latter of whom had a history of liver transplantation 2 years prior. Two of the patients who underwent surgery for IL intussusception had undergone major intra-abdominal surgeries (I due to neuroblastoma 6 months prior, I due to ganglioneuroma 3 weeks prior). The lymph nodes were the leading points in all 3 cases. In cases of SBI, history of abdominal surgery must be considered an important factor, increasing the probability of the need for surgery.

Among the cases of IL and J intussusception, a prominent difference in length of segments was observed on USG between those who required surgery and those for whom intussusceptions reduced without intervention. No spontaneously reduced intussusceptum was greater than $2.3 \mathrm{~cm}$ in length (min: I; max: 2.3; mean: I.8; median: $2 \mathrm{~cm}$ ), while all intussusceptums that required surgery were at least $4 \mathrm{~cm}$ (min: 4; max: 12; mean: 6.I; median:5.9). These cases were diagnosed as transient or benign SBI. Similarly, Doi et al. suggested the term benign SBls, which are diagnosed incidentally and resolve spontaneously. ${ }^{[25]}$

A limitation to the present study was the retrospective nature of the data. All procedures were conducted at a single institution, and number of patients was limited, allowing for descriptive, rather than comparative, analyses. USG was not performed by a single radiologist, but rather by the USG team of the radiology department, which is composed of academic staff members of similar experience and educational background working in collaboration. In addition to the relatively specific and easily detectible nature of intussusception signs on USG, this collaboration may be considered a factor that minimizes potential radiologist-dependent variation of USG accuracy. Randomized, controlled, prospective studies with greater numbers of patients are needed to confirm the present results.

Although the classic picture of vomiting, currant jelly stools, age less than 2 years, and palpable abdominal mass is reported in less than $25 \%$ of children, the present patient population had even lower incidences of palpable abdominal mass (6.2\%) and rectal bleeding (12.4\%). ${ }^{[14,26]}$ Easy accessibility of the hospital and high socio-economic status of the neighboring population may be the contributing factors, as heightened sensitivity of parents to symptoms may have led to earlier records of symptom onset. Further studies, designed to assess the impact of these and other possible factors are necessary. IC/CC intussusceptions and SBI should be considered 2 distinct subgroups. Urgent surgery is indicated in every case of intussusception with intestinal perforation and/or peritoneal irritation. Cases that present without acute abdomen should be managed according to the anatomic location of the intussuscepted segment.

For CC or IC intussusceptions with no sign of peritoneal 
irritation or intestinal perforation, hydrostatic or pneumatic reduction is the treatment choice. When reduction attempt fails, surgery is the next step. As there is no known nonsurgical reduction method for SBI, surgery may seem to be the only treatment option. However, reports of spontaneous reduction of SBI, which use the terms "transient" or "benign" intussusception face pediatric surgeons with the necessity to distinguish the cases who are likely to reduce spontaneously from the unlikely ones. ${ }^{[12,20,25]}$

Data of the present study indicates the unlikely need for intervention when $\mathrm{SBI}$ segments are shorter than $2.3 \mathrm{~cm}$. Following these cases with careful clinical monitoring, frequent physical examinations, and USG controls would be sufficient. Surgery should be considered for SBI segments longer than $4 \mathrm{~cm}$, as spontaneous reduction is unlikely. History of prior abdominal surgery should suggest high likelihood of need for urgent surgery in cases of SBI.

\section{Conflict of interest: None declared.}

\section{REFERENCES}

1. Bines J, Ivanoff B. Acute Intussusception in infants and children: Incidence, clinical presentation and management: a global perspective. Geneva: World Health Organization; 2002.

2. Pepper VK, Stanfill AB, Pearl RH. Diagnosis and management of pediatric appendicitis, intussusception, and Meckel diverticulum. Surg Clin North Am 2012;92:505-26. CrossRef

3. Huppertz HI, Soriano-Gabarró M, Grimprel E, Franco E, Mezner Z, Desselberger U, et al. Intussusception among young children in Europe. Pediatr Infect Dis J 2006;25(1 Suppl):22-9. CrossRef

4. Mandeville K, Chien M, Willyerd FA, Mandell G, Hostetler MA, Bulloch B. Intussusception: clinical presentations and imaging characteristics. Pediatr Emerg Care 2012;28:842-4. CrossRef

5. Ein SH, Stephens CA. Intussusception: 354 cases in 10 years. J Pediatr Surg 1971;6:16-27. CrossRef

6. Mansour AM, El Koutby M, El Barbary MM, Mohamed W, Shehata S, El Mohammady $\mathrm{H}$, et al. Enteric viral infections as potential risk factors for intussusception. J Infect Dev Ctries 2013;7:28-35. CrossRef

7. Nylund CM, Denson LA, Noel JM. Bacterial enteritis as a risk factor for childhood intussusception: a retrospective cohort study. J Pediatr 2010;156:761-5. CrossRef

8. Lappalainen S, Ylitalo S, Arola A, Halkosalo A, Räsänen S, Vesikari T. Simultaneous presence of human herpesvirus 6 and adenovirus infections in intestinal intussusception of young children. Acta Paediatr 2012;101:663-70. CrossRef

9. Hsu HY, Kao CL, Huang LM, Ni YH, Lai HS, Lin FY, et al. Viral etiology of intussusception in Taiwanese childhood. Pediatr Infect Dis J
1998;17:893-8. CrossRef

10. Bines JE, Liem NT, Justice FA, Son TN, Kirkwood CD, de Campo M, et al. Risk factors for intussusception in infants in Vietnam and Australia: adenovirus implicated, but not rotavirus. J Pediatr 2006;149:452-60.

11. Sigmound EH, Daneman A. Intussusception. In: Grosfeld JL, O'Neil JA, Fonkalsrud EW, editors. Pediatric surgery. 6th ed. Philadelphia: Mosby Year Book Inc; 2006. p. 1313-41.

12. Zhang Y, Bai YZ, Li SX, Liu SJ, Ren WD, Zheng LQ. Sonographic findings predictive of the need for surgical management in pediatric patients with small bowel intussusceptions. Langenbecks Arch Surg 2011;396:1035-40. CrossRef

13. Munden MM, Bruzzi JF, Coley BD, Munden RF. Sonography of pediatric small-bowel intussusception: differentiating surgical from nonsurgical cases. AJR Am J Roentgenol 2007;188:275-9. CrossRef

14. Fallon SC, Lopez ME, Zhang W, Brandt ML, Wesson DE, Lee TC, et al. Risk factors for surgery in pediatric intussusception in the era of pneumatic reduction. J Pediatr Surg 2013;48:1032-6. CrossRef

15. Betz BW, Hagedorn JE, Guikema JS, Barnes CL. Therapeutic enema for pediatric ileocolic intussusception: using a balloon catheter improves efficacy. Emerg Radiol 2013;20:385-91. CrossRef

16. Tran LA, Yoshida LM, Nakagomi T, Gauchan P, Ariyoshi K, Anh DD, et al. A High Incidence of Intussusception Revealed by a Retrospective Hospital-Based Study in Nha Trang, Vietnam between 2009 and 2011. Trop Med Health 2013;41:121-7. CrossRef

17. Lochhead A, Jamjoom R, Ratnapalan S. Intussusception in children presenting to the emergency department. Clin Pediatr (Phila) 2013;52:1029-33. CrossRef

18. Daneman A, Navarro O. Intussusception. Part 2: An update on the evolution of management. Pediatr Radiol 2004;34:97-108; quiz 187. CrossRef

19. Katz M, Phelan E, Carlin JB, Beasley SW. Gas enema for the reduction of intussusception: relationship between clinical signs and symptoms and outcome. AJR Am J Roentgenol 1993;160:363-6. CrossRef

20. Kornecki A, Daneman A, Navarro O, Connolly B, Manson D, Alton DJ. Spontaneous reduction of intussusception: clinical spectrum, management and outcome. Pediatr Radiol 2000;30:58-63. CrossRef

21. Merine D, Fishman EK, Jones B, Siegelman SS. Enteroenteric intussusception: CT findings in nine patients. AJR Am J Roentgenol 1987;148:1129-32. CrossRef

22. Cox TD, Winters WD, Weinberger E. CT of intussusception in the pediatric patient: diagnosis and pitfalls. Pediatr Radiol 1996;26:26-32.

23. Kim JH. US features of transient small bowel intussusception in pediatric patients. Korean J Radiol 2004;5:178-84. CrossRef

24. Strouse PJ, DiPietro MA, Saez F. Transient small-bowel intussusception in children on CT. Pediatr Radiol 2003;33:316-20. CrossRef

25. Doi O, Aoyama K, Hutson JM. Twenty-one cases of small bowel intussusception: the pathophysiology of idiopathic intussusception and the concept of benign small bowel intussusception. Pediatr Surg Int 2004;20:140-3. CrossRef

26. Kaiser AD, Applegate KE, Ladd AP. Current success in the treatment of intussusception in children. Surgery 2007;142:469-77. CrossRef 
ORİJINAL ÇALIŞMA - ÖZET

\section{Her intususepsiyon tedavisi acil girişim veya cerrahi midir?}

Dr. Lütfi Hakan Güney, Dr. Ender Fakıoğlu, Dr. Tuğba Acer, Dr. İbrahim Ötgün, Dr. Esra Elif Arslan, Dr. Müge Sağnak Akıllı, Dr. Akgün Hiçsönmez

Başkent Üniversitesi Tıp Fakültesi, Çocuk Cerrahisi Anabilim Dalı, Ankara

AMAÇ: İntususepsiyon, çocuklarda akut apandisitten sonra en yaygın akut karın sebebidir. İntususepsiyon deneyimlerimizi, ileo-kolik ve ince bağırsak intususepsiyonlarına yaklaşım seçeneklerini gözden geçirmeyi hedefledik.

GEREÇ VE YÖNTEM: Temmuz 2002-Eylül 2014 yılları arasında kliniğimizde intususepsiyon tanısı almış olguların kayıtları tarandı; yaş, cinsiyet, klinik bulgular, başvuru süresi, ultrasonografi bulguları ve uygulanan tedavi seçenekleri ve sonuçları değerlendirildi.

BULGULAR: Toplamda 8 I olgunun 52'si erkek, 29'u kız, ortalama yaşları 10.6 aydı. İntususepsiyon 52 hastada ileokolik, 26 hastada ileoileal, üç hastada jejunojejunaldi. On dokuz (\%23.5) olguda cerrahi, tümü ileokolik 45 (\%55.5) olguda hidrostatik redüksiyon uygulandı. Periton irritasyonu bulgusu olmayan 17 (\%2I) hasta fiziksel inceleme, ultrasonografi ve klinik izleme alındı. Tamamı ince bağırsakta olan invajine segmentlerinin uzunlukları ultrasonografik olarak I.8-2.3 cm arasında ölçülen bu hastalarda komplikasyonsuz spontan redüksiyon izlendi. Cerrahi uygulanan hastaların tümünde invajine segment en az $4 \mathrm{~cm}$ uzunluğundaydı. Rezeksiyon yapılan dört hastanın üçünde cerrahi öyküsü vardı.

TARTIŞMA: Periton irritasyonu bulguları olan tüm intususepsiyon olgularında tedavi cerrahidir. Diğer durumlarda, tedavi yaklaşımı açısından ince bağırsak intususepsiyonları ileokolik intususepsiyonlardan ayrı değerlendirilmelidir. İnce bağırsak intususepsiyonu 2.3 cm'den kısaysa ultrasonografi desteğiyle klinik izlem güvenlidir; 4 cm'den uzun ve geçirilmiş karın cerrahisi varsa cerrahi müdahale ön planda düşünülmelidir.

Anahtar sözcükler: benign intususepsiyon; geçici intususepsiyon; ince bağırsak intususepsiyonu; intususepsiyon; spontan redüksiyon.

Ulus Travma Acil Cerrahi Derg 2016;22(2):139-144 doi: 10.5505/tjtes.2015.060I3 